\title{
Prototype Perhitungan Meterial Conveyor Berbasiskan Mikrokontroler Arduino Uno
}

\author{
Fredy Susanto ${ }^{l}$; Diah Aryani ${ }^{2}$; Anita $b$ wandanaya ${ }^{3}$ \\ ${ }^{1}$ Sistem Komputer, Universitas Raharja \\ ${ }^{2}$ Teknik informatika, Universitas Indonusa Esa Unggul \\ ${ }^{3}$ Sistem Informasi, Universitas Raharja \\ Jl. Jenderal Sudirman No.40 Cikokol- Tangerang 15117 \\ 1 fredy@raharja.info \\ 2 diah.aryani05@gmail.com \\ 3 anita@raharja.info
}

\begin{abstract}
In the development of technology in the field of electronics today, many benefits can be felt by most humans. With development of the industrial revolution and the increasing variety of types of industries, greatly affect the level of work efficiency. The problem of calculating the number of products produced is a dilemma to overcome, because it requires accuracy and concentration. While human resources are very limited. Therefore a prototype was designed to replace human work, so the results can be fast and precise. The research method by combining several counter systems and microcontrollers into a useful system. This prototype aims to calculate the number of material goods produced. Method of problem identification, prototype, literature study, analysis, and evaluation. Counter system embedded in Arduino uni microcontroller combined with conveyori works if the goods pass the sensor on the conveyor, the goods will be counted, will automatically be displayed on the LCD and the buzzer will sound then will calculated daily or can be set as desired. Thus anyone who has an interest in this process, will know the number of items that are counted in real time, precisely and quickly. Reporting the process of calculating the goods can be recap and known at any time. With this system, it can help human work so as to reduce errors.
\end{abstract}

Keywords: Automatic calculating equipment, Conveyor, Arduino UNO

\begin{abstract}
ABSTRAK
Dalam perkembangan ilmu teknologi dibidang elektronika khusu nya sistem kendali sekarang ini, banyak manfaat yang bisa dirasakan oleh sebagian besar manusia. Dengan perkembangan revolusi industry dan semakin meningkatnya ragam jenis industrinya, sangat mempengaruhi tingkat efisiensi kerja,. Permasalahan perhitungan jumlah barang hasil produksi sangatlah menjadi dilema untuk diatasi, karena membutuhkan ketelitian dan konsentrasi. Sedangkan sumber daya manusia sangat terbatas. Maka dari itu dirancang suatu prototype untuk menggantikan pekerjaan manusia, sehingga hasilnya bisa cepat dan tepat. Metode penelitian dengan memadukan beberapa sistem counter serta Mikrokontroler menjadi sebuah sistem yang bermanfaat. Prototype yang dibuat bertujuan menghitung jumlah barang material hasil produksi. Metode identifikasi masalah, prototype, studi literature, analisa, dan evaluasi. Sistem counter yang ditanamkan kepada mikrokontroler Arduino uni dipadukan dengan conveyori bekerja jika barang melewati sensor pada conveyor maka barang akan terhitung, secara otomatis akan ditampilkan pada LCD dan buzzer akan berbunyi kemudian akan dikalkulasi perhari atau dapat disetting sesuai keinginan. Dengan demikian siapapun yang berkepentingan dengan proses ini, akan mengetahui jumlah barang yang terhitung secara real time, tepat dan cepat. Pelaporan proses perhitungan barang dapat direkap dan diketahui kapan saja. Dengan sistem ini, dapat membantu pekerjaan manusia sehingga dapat mengurangi kesalahan.
\end{abstract}

Kata kunci: Alat hitung Otomatis, Conveyor, Arduino UNO 


\section{PENDAHULUAN}

Dalam perkembangan ilmu teknologi dibidang elektronika khususnya sistem kendali dan embedded sistem sekarang ini, banyak manfaat dan kegunaan yang bisa dirasakan oleh manusia, diantarnya adalah untuk mempermudah segala macam pekerjaan dibidang industri/ revolusi industri. Sejalan dengan pesatnya kebutuhan hidup masyarakat dan teknologi yang semakin modern, maka dari itu dirancang alat yang mampu mempermudah aktifitas manusia menggunakan sensor infrared dengan presisi, ketelitian dan kecepatan yang sangat tinggi. Mikrokontroller dalam hal ini Arduino dapat membantu beberapa aktifitas manusia dalam sebuah pengamatan atau monitoring system. Sistem penghitungan jumlah barang yang melewati sensor secara otomatis ini memanfaatkan adanya cahaya infrared sebagai pendeteksi adanya barang yang melintasi dengan antrian pada conveyor. Sinyal-sinyal data yang dikirimkan oleh sensor infrared lah yang nantinyadigunakan untuk mendeteksi barang- barang yang melintas di conveyor dan serta pemberi keterangan mengenai beberapa banyak barang yang sudah terhitung (counting)

Suatu skema rangkaian elektronik yang sering digunakan pada counter, memerlukan suatu alat pencacah (counter) yang dapatmelakukan perhitungan ke atas dan bisa juga melakukan perhitungan ke bawah. Alat pencacah (counter) yang menghitung seperti ini disebut dengan binary up down counter. Alat ini dapat melakukan perhitungan ke atas dan ke bawah dengan mengatur suatu alat pengontrol tertentu secara real time.

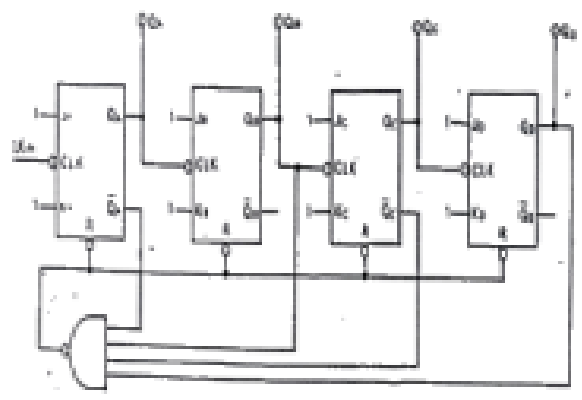

Gambar 1. Pencacah asinkron.

Gambar diatas menerangkan dengan tombol up dan down dapat melakukan proses melakukan perhitungan dari atas atau dari bawah. Gambar diatas adalah pencacah/counter Asinkron dimana sinyal yang dihitung tidak serentak, berbeda dengan counter sinkron, sinyal yang dihitung berasal dari flip-flop yang serentak. Oleh karena hal tersebut, proses perhitungan pencacah / counter sinkron lebih cepat dan tepat, dibandingkan dengan pencacah asinkron. Berikut gambar sinkron.

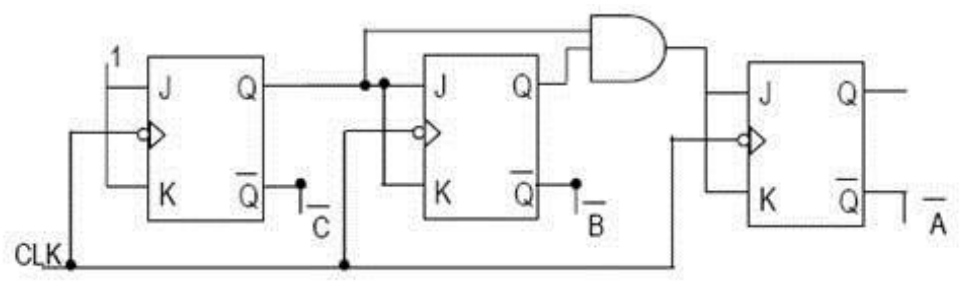

Gambar 2. Pencacah sinkron.

Jenis-jenis conveyor ada beberapa, diantaranya adalah

1. Pada Plat screw conveyor Bagian ini dibuat dari plat yang berbentuk lingkaran yang kemudian salah satu sisinya dipotong, lalu kemudian direnggangkan dan disamping satu 
sama lain dengan proses pengelasan dengan ukuran pitch yang telah ditentukan, dibagian inilah yang dapat menghasilkan pasir hasil dari penggilingan. Menurut Shingley, [3] untuk mencari massa pada plat screw ini dapat diasumsikan bentuknya menyerupai piringan, maka di dapat menggunakan persamaan:

$$
m=\rho\left[\frac{\pi}{4}\left(D^{2}-d^{2}\right) t\right]
$$

2. Rumah Screw Conveyor Bagian ini dapat berfungsi sebagai tempat untuk dudukan screw conveyor dan sekaligus sebagai jalan untuk pasir yang digiling. Rumah screw conveyor ini terbuat dari bahan besi pipa yang dibentuk sedemikian rupa sesuai dengan ukuran yang telah di perhitungkan. Untuk mencari volume rumah screw conveyor digunakan persamaan:

$$
V=\frac{\pi}{4}\left(D_{1}\right)^{2} L
$$

Berdasarkan Zemansky, [4] maka massa rumah screw conveyor menggunakan persamaan:

$$
m=\pi \cdot L \cdot \rho\left(R_{2}^{2}-R_{1}\right)
$$

3. Poros screw conveyor, Pada Poros ini merupakan tempat melekatnya plat screw, di mana pelekatannya dilakukan melalui proses pengelasan.

4. Bantalan Bantalan adalah suatu bentuk elemen mesin yang dapat menumpu beban diantara bagian yang tempat berputar terutama terhadap titik pusat agar gerakannya berlangsung secara ringan, aman dan tahan lama. Bantalannya harus cukup kuat untuk memungkinkan titik pusat serta elemen-elemen mesin lainnya bekerja dengan baik Dalam prototype ini bantalan yang dipergunakan adalah bantalan gelinding, karena bantalan nya, berfungsi menahan titik pusat screw conveyor yang berputar pada sambungan, sehingga dapat berputar menjadi lebih stabil dan aus yang ditimbulkan dapat dihalus.

5. Titik pusat merupakan suatu elemen mesin yang dapat berfungsi untuk meneruskan daya dan putaran selama mesin beroperasi, sehingga dikatakan bahwa poros merupakan peran utama dalam sistem transmisi. Pembebanan pada poros tergantung besarnya daya dan putaran mesin yang diteruskan, serta pengaruh daya yang ditimbulkan oleh bagian-bagian mesin yang berputar bersama poros. Penggunaan mesin perkakas untuk mendesain elemen mesin seperti poros saat ini masih dinilai efektif.

6. Sabuk Sabuk merupakan suatu elemen mesin yang dipakai untuk memindahkan daya anara dua titik pusat yang sejajar. Titik pusat harus berpisah pada jarak minimum tertentu yang tergantung pada jenis pemakaian sabuk agar bekerja efesien. Jarak yang jauh antara dua titik pusat sering tidak memungkinkan dilakukan transmisi langsung dengan roda gigi. Dalam hal ini salah satu cara metransmisikan putaran adalah dengan menggunakan sabuk.[5]

Dalam penggunaan coneveyor diperlukan sabuk/belt conveyor, Belt conveyor adalah sabuk yang menyerupai karet yang tidak berujung terdiri dari beberapa lapisan diperkeras dengan bantuan 
fiber dan atau kawat baja untuk menghasilkan kekuatan pada belt. Belt conveyor dapat digunakan untuk memindahkan muatan satuan (unit load) maupun muatan curah (bulk load) sepanjang garis lurus (horizontal).[6]

Arduino adalah sebuah dapat juga sebuah mikrokontroler yang menggunakan komputasi fisik open source berbasiskan Rangkaian input / output sederhana (I/O) dan lingkungan pengembangan yang mengimplementasikan bahasa Processing atau bahasa mesin. Arduino dapat digunakan untuk mengembangkan rangkaian kontrol mandiri atau dapat dihubungkan ke perangkat lunak pada komputer. IDE (Integrated Development Environment) adalah Arduino yang bersifat open source.

Arduino UNO ada fasilitas untuk komunikasi dengan sebuah computer dapat terjadi, Arduino atau mikrokontroler lainnya. Atmega 328 menyediakan serial komunikasi UART TTL (5V), yang tersedia pada pin digital 0 (RX) dan 1 (TX). Sebuah Atmega 16U2 pada channel board serial koneksi melalui USB dan muncul sebagai sebuah port virtual ke software pada komputer. Firmware 16U2 menggunakan driver USB COM yang standar, dan driver eksternal tidak diperlukan. LED RX dan TX pada board akan menyala seketika data sedang melakukan transmit melalui chip USB-to-serial dan koneksi USB pada komputer (tapi tidak terjadi pada komunikasi serial pada pin 0 dan 1).[7]

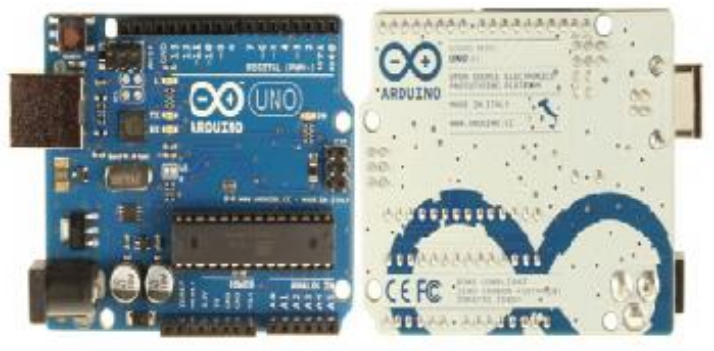

Gambar 3. Papan Arduino Uno.

Arduino dapat dikelasifikasikan menjadi 2 bagian penting, yaitu adalah pertama, hardware yang terdiri dari banyak komponen, sperti gambar 3. Yang kedua adalah software yaitu arduino IDE software di buat dari bahasa pemrograman, bahasa c. Sebagai penghubung data-data dengan hardware. Sensor Infrared Unit Sensor cahaya berfungsi untuk melakukan deteksi ada tidaknya barang yang lewat pada area conveyorr. Unit yang ada ini menggunakan sebuah LDR pada bagian pemancar.[12]

Penggunaan sistem Arduino Uno ini adalah penggunaan sistem cerdas yang hemat tenaga dan energy, mendukung penghematan energy yang terjadi.[15]

LDR atau light Dependent Resistor merupakan salah satu jenis resistor yang nilai hambatannya dapat dipengaruhi oleh cahaya yang diterima olehnya. Besaran nilai hambatan pada LDR tergantung pada besar kecilnya intensitas cahaya yang diterima oleh LDR itu sendiri. Contoh penggunaannya adalah pada lampu taman dan lampu di jalan yang bisa menyala di malam hari dan padam di siang hari secara otomatis. Atau bisa juga kita gunakan di kamar kita sendiri.[13]

Buzzer merupakan sebuah elektronika yang nertujuan mengubah getaran listrik menjadi sebuah getaran suara. Dasarnya cara kerja alat buzzer hampir sama dengan loudspeaker, Buzzer terdiri atas kumparan yang terpasang pada diafragma.[14] 


\section{METODE PENELITIAN}

Pada metode penelitian ini, penulis mengambil tahapan-tahapan sebagai berikut, yaitu: permasalahan yang ada dan dihadapi, dari permasalahan itu dirinci kembali apasaja yang menjadi permasalahannya, kemudian mengambil atau mengumpulkan data-data yang diruntut kembali menjadi data embedded apa saja dan data-data yang mendukung lainnya. Selanjutnya adalah metode apa yang dipakai dalam mengatasi permasalahan, yang terakhir membuat prototype untuk mengujian model.

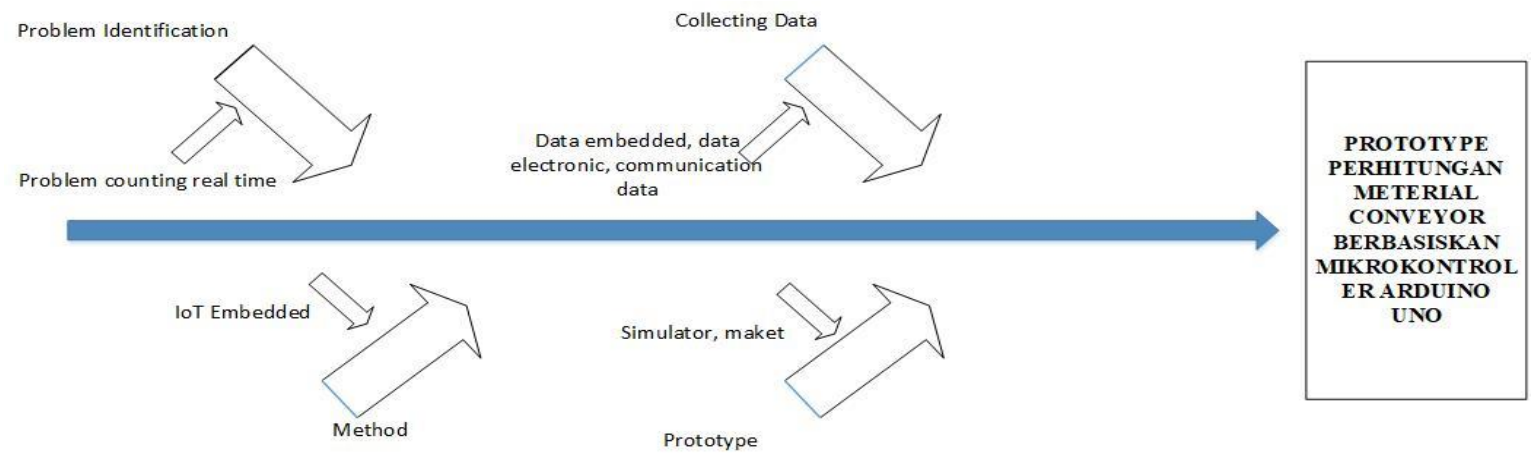

Gambar 4. Skema metode

Bahasa pemrograman yang digunakan untuk membuat prototype adalah bahasa c, sedangkan pengumpulan data untuk input nya adalah sensor-sensor yang terkoneksi dengan Mikrokontroller arduino uno. Selain menggunakan metode diatas, penulis juga menggunakan metode analisa swot untuk mengukur penelitian yang didapat, proses, kemudian luarannya. Metode nya sebagai berikut:

Tabel 1. Analisa Swot

\begin{tabular}{|c|c|c|c|c|c|}
\hline \multirow{7}{*}{ 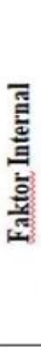 } & & Kekuatan/Strengluts (S) & & Peluang/Opportum & ties (O) \\
\hline & 1 & Tersedianya sarana pendukung & 1 & \multicolumn{2}{|c|}{ Perkembangan teknologi yang } \\
\hline & & teknologi informasi & & semakin cepat & \\
\hline & 2 & $\begin{array}{l}\text { Keuangan perusahaan yang } \\
\text { mendukung }\end{array}$ & 2 & \multicolumn{2}{|c|}{$\begin{array}{l}\text { Kebutuhan pelanggan yang } \\
\text { semakin banyak }\end{array}$} \\
\hline & 3 & $\begin{array}{l}\text { Mempunyai SDM yang } \\
\text { berkualifikasi di bidang teknologi }\end{array}$ & 3 & \multicolumn{2}{|c|}{$\begin{array}{l}\text { Ekspansi ekspor ke beberapa } \\
\text { negara }\end{array}$} \\
\hline & 4 & $\begin{array}{l}\text { Manajemen yang diterapkan sudah } \\
\text { maksimal }\end{array}$ & 4 & \multirow{2}{*}{\multicolumn{2}{|c|}{$\begin{array}{l}\text { Produsen lain yang masih sedikit } \\
\text { Jumlah konsumen yang } \\
\text { meningkat setiap bulannya }\end{array}$}} \\
\hline & 5 & Harga jual produk terjangkau & 5 & & \\
\hline \multirow{6}{*}{ 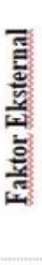 } & & Kelemahan/Weakness (W) & \multicolumn{2}{|r|}{ Ancaman/Tlireats } & (T) \\
\hline & 1 & Kurang memanfaatkan teknologi & 1 & Banyaknya kompetitor & \\
\hline & & Informasi & 2 & \multicolumn{2}{|c|}{ Banyak virus yang beredar } \\
\hline & 2 & Sering terjadi human error & 3 & \multicolumn{2}{|c|}{ Krisis global yang mengancam } \\
\hline & 3 & $\begin{array}{l}\text { Kurangnya pemeliharaan terhadap } \\
\text { peralatan kerja }\end{array}$ & 4 & \multicolumn{2}{|c|}{$\begin{array}{l}\text { Produsen lain yang jauh lebih } \\
\text { berkembang }\end{array}$} \\
\hline & & & 5 & \multicolumn{2}{|c|}{$\begin{array}{l}\text { Suku bunga bank mempengaruhi } \\
\text { daya beli }\end{array}$} \\
\hline
\end{tabular}

\subsection{Literature Review}

Literature review ini berfungsi sebagai pembanding (memperbaiki kekurangan) hasil penelitian lain, menambahkan literature dan sebagai media pencari kesamaan dalam menghindari plagiatisme dalam penulisan penelitian.

1. Penelitian yang dilakukan oleh Subhankar Chattoraj, Aditya Chakraborty, "Bidirectional Visitor Counter with Automatic Room Light Controller and Arduino as the master controller", Counter is incremented by one value and the light in theroom will 
automatically switched $O N$ and when any one leavesthe room then the counter is decremented by one value and the light will be only switched OFF until all the persons in the room go out. Department of Electronics \& Communication Engineering Techno India University [8]

2. Penelitian yang dilakukan oleh Bruno F. Carvalho, Caio C. M. Silva, Alessandra M. Silva, Fábio Buiati and Rafael Timóteo, "Two different technologies were used, aiming to verify the best option to design a counter device with low-cost microcontrollers and sensors". Experimental results shows that in controlled environments the IoT person counter has a satisfactory accuracy. Some limitations were also identified in order to clarify the scenarios where those devices can be used. Universidade de Brasília, Campus Darcy Ribeiro, Brasília, Brazil [9]

3. Penelitian yang dilakukan oleh Harpreet Singh Bedi, Nikhil Goyal, Sunil Kumar and Avinash Gupta, "Smart Trolley using Smart Phone and Arduino" The main purpose of supermarkets is to provide availability of all the products and save the time of the customers but sometimes customer gets frustrated while waiting in the queue at billing counter and sometimes they get confused while comparing the total price of all the products with the budget in the pocket before billing. To overcome these problems, we have designed a smart trolley using a smart phone and Arduino. With this system, there is no need for customer to wait in the queue for the scanning for the product items for billing purpose. Department of Electronics and Electrical Engineering, Lovely Professional University, Phagwara, Punjab, India [10]

\section{HASIL DAN PEMBAHASAN}

Dalam perancangan prototype perhitung material conveyor jumlah barang dengan Arduino membutuhkan beberapa komponen elektonika, diantaranya adalah: Laser sebagai input. Arduino uno sebagai media pemrosesan serta untuk perlengkapan atau device penunjang lainnya agar suapaya sistem tersebut dapat berjalan dengan baik sesuai dengan yang diharapkan. Untuk supaya mudah dipahami penulis membuat diagram block dan alur kerjanya:

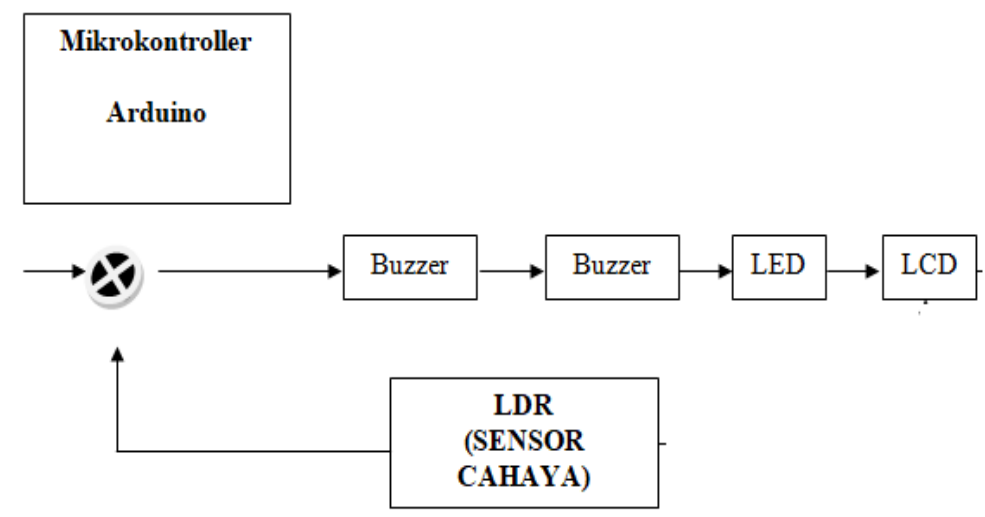

Gambar 5. Blok diagram system

Setelah dilakukan perancangan alat dari seluruh komponen serta bahan yang digunakan, maka rangkaian sistem secara keseluruhan akan terlihat seperti gambar dibawah ini, sebagai berikut: 


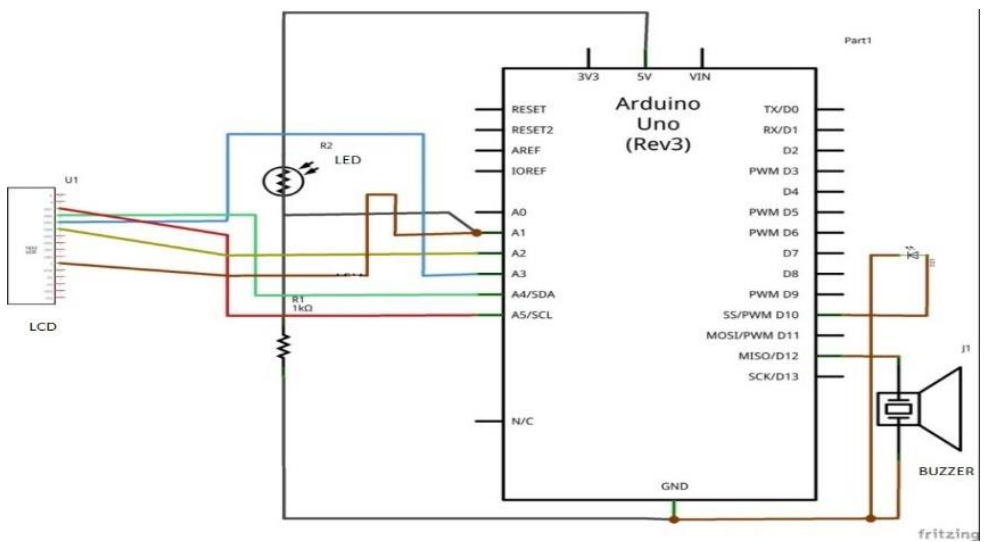

Gambar 6. Rangkaian alat

Pada pembuatan sistem kendali diperlukan gambar untuk menjelaskan alur dan langkah langkah dari sistem kerja sistem yang dibuat, agar dapat memberikan penjelasan dalam bentuk gambar. Penjelasan yang berupa skema gambar proses kerja sebuah sistem. Tujuannya dari pembuatan flowchart adalah agar lebih mudah pembaca dan pembuat sistem itu sendiri untuk dan memahami langkah-langkah serta cara kerja sebuah sistem yang dibuat. Dari penelitian yang dilakukan menghasilkan flowchart dibawah ini:

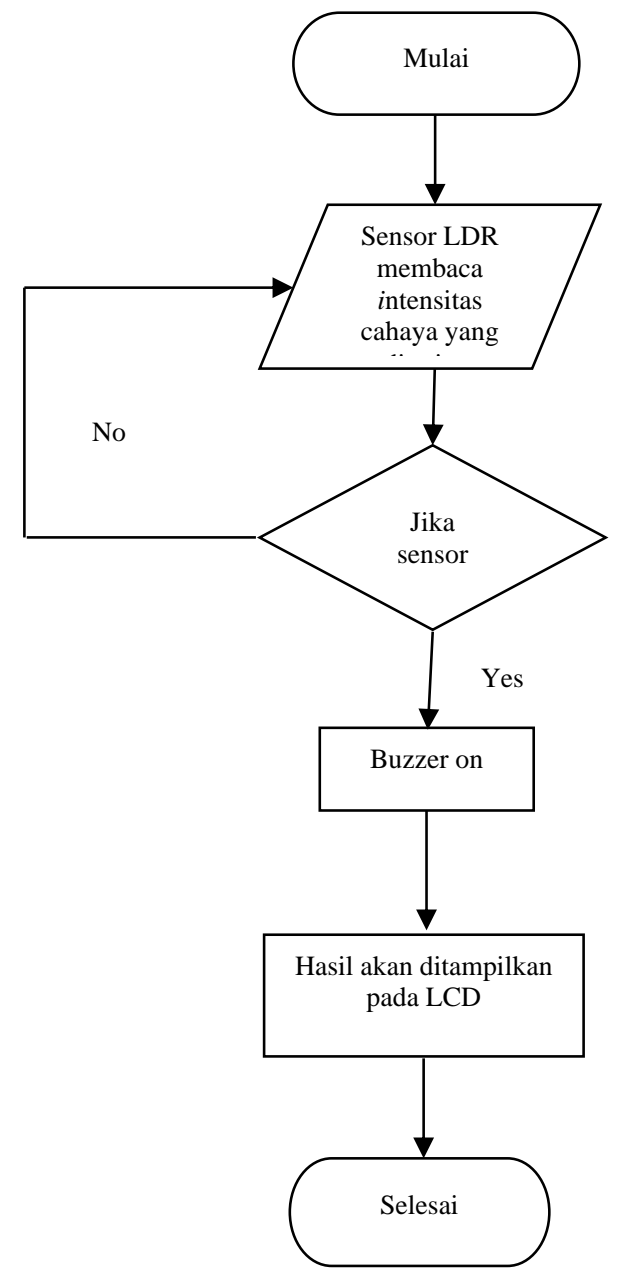

Gambar 7. Flow chat sistem 
Program yang dibuat menggunakan Bahasa c, IDE arduino, data input berasal dari sensor LDR, diproses pada Arduino, keluarannya LCD dan buzzer, saat barang-barang melintas.

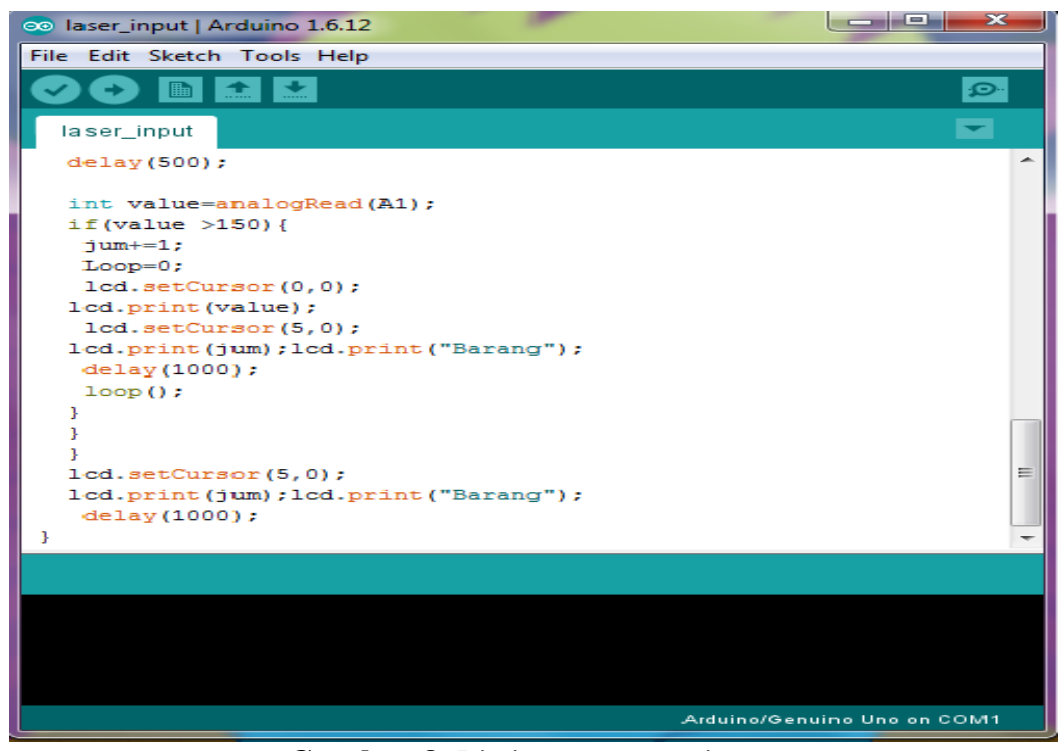

Gambar 8. Listing program sistem

Tabel berikut ini adalah hasil analisa dan percobaan pada Arduino, penggerak conveyor, sesensor LDR, tampilan LCD hingga bunyi buzzer yang dihasilkan

Tabel 2. Analisa Hasil

\begin{tabular}{|c|l|l|c|}
\hline No & \multicolumn{1}{|c|}{ Nama } & \multicolumn{1}{|c|}{ Keterangan } & $\begin{array}{c}\text { Kondisi/ } \\
\text { keadaan }\end{array}$ \\
\hline 1 & Module LDR & $\begin{array}{l}\text { Input ke } \\
\text { Arduino Uno, } \\
\text { sensor barang, } \\
\text { apakah ada } \\
\text { barang melintas }\end{array}$ & Ok, (Tx dan Rx) \\
\hline 2 & Pergerakan Conveyor & $\begin{array}{l}\text { Dengan Gear } \\
\text { Roda }\end{array}$ & $\begin{array}{c}\text { Ok (bergerak } \\
\text { maju) }\end{array}$ \\
\hline 3 & LCD & $\begin{array}{l}\text { Tampilan / } \\
\text { output hasil } \\
\text { perhitungan }\end{array}$ & $\begin{array}{c}\text { Ok (menampilkan } \\
\text { counter) }\end{array}$ \\
\hline 4 & Buzzer & Output Audio & Ok, (bunyi sesuai) \\
\hline 5 & LED & Tanda/indikator & ok \\
\hline
\end{tabular}

\section{KESIMPULAN DAN SARAN}

Kesimpulan dari sistem ini adalah sistem penghitung jumlah barang ini merupakan Arduino Uno sebagai komponen utama sebagai masukan program yang dibentuk untuk memberikan instruksi pada komponen-komponen yang lainnya. LED yang berfungsi untuk indikator yang menunjukkan bahwa alat sudah bekerja setelah di berikan power berupa arus listrik. LDR digunakan sebagai penangkap cahaya dari laser yang akan dibaca nilai sensornya kedalam Arduino, setelah nilai didapatkan maka akan dihitung barang yang melewati laser tersebut, setiap barang yang melewati laser maka buzzer akan berbunyi beep satu kali, setelah itu ditampilkan ke LCD jumlah barang yang melewati laser tersebut. Hasil lengkap dapat dilihat pada table dibawah ini. 
Diharapkan sistem ini dapat membantu pekerjaan manusia, sehingga ketelitian dan kinerja dapat ditingkatkan serta kinerja produksi secara kesuluruhan dapat lebih baik. Untuk saran dari penelitian ini adalah tentunya sistem ini dapat dikembangkan kearah yang lebih modern atau lebih baik lagi, dimana monitoring hasil dari perhitungan conveyor dapat diketahui melalui aplikasi mobile.

\section{UCAPAN TERIMAKASIH}

Penulis mengucapkan terima kasih kepada Institut PLN yang telah memberikan kesempatan untuk penulisan pada jurnal PETIR ini, tidak lupa pada Universitas Raharja tempat penulis bernaung sebagai Dosen yang telah memberi dukungan yang membantu pelaksanaan penelitian dan atau penulisan artikel.

\section{DAFTAR PUSTAKA}

[1] Eko Nuryanto, "aplikasi jk flip-flop untuk merancang decade counter asinkron", Orbith VOL. 13 NO. 2 Juli 2017, Politeknik Negri Semarang

[2] https://adityarizki.net/tutorial-teknik-digital-rangkaian-pencacah-counter/ diakses 17 Juni 2020

[3] Shingley.J.E, 1999. Perencanaan Teknik Mesin. Jilid I. Erlangga. Jakarta.

[4] Sear, Zemansky, 1982. Fisika Untuk Universitas. Bina Cipta. Bandung

[5] Rahman, abdul. "prototype screw conveyor mesin pendaur ulang pasir cetak 10 ton/jam", Seminar Nasional Sain dan Teknologi, Universitas Malikulsalleh, Aceh. 2017

[6] Suryadi, dedi. "rancang bangun prototype belt conveyor" Univesitas Muhammaddyah Sumatra Utara. 2018

[7] Steven jendri sokop, Dringhuzen J. Mamahit, Sherwin R.U.A. Sompie, "Trainer Periferal Antarmuka Berbasis Mikrokontroler Arduino Uno" E-Journal Teknik Elektro dan Komputer vol.5 no.3 (2016), ISSN : 2301-8402, Jurusan Teknik Elektro-FT. UNSRAT, Manado

[8] Subhankar Chattoraj, Aditya Chakraborty, Department of Electronics \& Communication Engineering Techno India University "Bidirectional Visitor Counter with Automatic Room Light Controller and Arduino as the master controller" International Journal of Scientific and Research Publications, Volume 6, Issue 7, July 2016357 ISSN 2250-3153

[9] Bruno F. Carvalho, Caio C. M. Silva, Alessandra M. Silva, Fábio Buiati and Rafael Timóteo, Universidade de Brasília, Campus Darcy Ribeiro, Brasília, Brazil, "Two different technologies were used, aiming to verify the best option to design a counter device with low-cost microcontrollers and sensors" Proceedings of the International Conference on Internet of Things and Big Data (IoTBD 2016), pages 129-136 ISBN: 978-989-758-183-0

[10] Harpreet Singh Bedi, Nikhil Goyal, Sunil Kumar and Avinash Gupta, Department of Electronics and Electrical Engineering, Lovely Professional University, Phagwara, Punjab, India, "Smart Trolley using Smart Phone and Arduino" Journal of Electrical \& Electronic Systems Published May 23, 2017

[11] Yusuf Abdullahi Badamasi, The Working Principle Of An Arduino, University Abuja, Nigeria 2014

[12] Decy Nataliyan, "Sistem Monitoring Parkir Mobil menggunakan Sensor Infrared berbasis RASPBERRY PI”, Jurnal TELKOMNIKA, Teknik Elektro Itenas | No.1 | Vol. 2 Institut Teknologi Nasional Bandung Januari - Juni 2014 
[13] Supatmi, Sri, Majalah Ilmiah Unikom, "PENGARUH SENSOR LDR TERHADAP PENGONTROLAN LAMPU”, Vol.8, No. 2 Jurusan Teknik Komputer Universitas Komputer Indonesia 2011.

[14] Sumarno, Handri, "Perancangan Alat Monitoring Pendeteksi Suara di Ruangan Bayi RS Vita Insani Berbasis Arduino Menggunakan Buzzer", JURNAL MEDIA INFORMATIKA BUDIDARM, Volume 4, Nomor 1, Januari 2020

[15] J.Chandramohan, "Intelligent Smart Home Automation and Security System Using Arduino and Wi-fi", International Journal Of Engineering And Computer Science ISSN:2319-7242 Volume 6 Issue 3 March 2017 